\title{
KETERLIBATAN MEREK DAN MOTIF KONSUMEN \\ DALAM KOMUNIKASI E-WORD OF MOUTH \\ MELALUI SOSIAL MEDIA
}

\author{
Diesyana Ajeng Pramesti \\ Farida \\ Wawan Satdyo Nugroho \\ Universitas Muhammadiyah Magelang \\ diesyana.ajeng@ummgl.ac.id
}

\begin{abstract}
The objective of this research is to test and analize brand involvement ang motives consumer in the electronic-word of mouth communication engagement in social media. The kinds of electronic-word of mouth communication in social media such as writing, liking, sharing, recomending, commenting, and tweeting. The subject of this research are people who ever makes an electronic-word of mouth in social media. The object of this research are Facebook, Titter, Google+, and Alexa. The method used in the research is survey by using purposive sampling technique to 200 sosial media's users in Indonesia that ever wrote a testimonial.. Datas analyze using SPSS and hypothesis testing using simple linear regression. This findings shows brand involvement, product involvement, self involvement, and advice seeking has positive and significant effect to electronic-word of mouth communication in social media, and the other hand, other involvement has positive effect but not significant, and also need for social interaction has negative effect to the electronic-word of mouth communication in social media. In means in the research, there are 4 hypothesis supported and 2 hypothesis not supported.
\end{abstract}

Keywords: e-word of mouth, brand involvement, consumer motives, social media

\section{PENDAHULUAN}

Perkembangan bisnis dalam jaringan di Indonesia semakin berkembang sejalan dengan semakin mudahnya akses internet bagi masyarakat. Koneksi jaringan internet dapat dengan mudah ditemukan di mana saja, sehingga memudahkan masyarakat Indonesia dalam menggunakan internet. Pengguna internet mulai di Indonesia bertumbuh di tahun 2014 sebesar 27 juta jiwa dan terus meningkat hingga mencapai
82 juta jiwa (Kementerian Komunikasi dan Informatika RI, 2016). Bahkan perkembangan dunia maya saat ini didukung dengan mudahnya pengaksesan internet melalui smartphone sehingga siapapun mudah mengakses internet dan bersosial media dimanapun dan kapanpun juga. Dari fenomena tersebut dapat disimpulkan bahwa Indonesia merupakan pasar pengembangan bisnis online. Dengan semakin meningkatnya jumlah pengguna internet di Indonesia, maka Indonesia menjadi salah satu pasar teknologi 
yang menjanjikan di Asia. Selain itu akan terbuka peluang untuk berbisnis online melalui media internet. Dari data yang ada menunjukkan bahwa 77,81\% internet digunakan untuk mencari informasi barang-barang yang diinginkan dan diperlukan, melebihi penggunaan internet seperti pada fungsi dasarnya yang hanya sebesar $61,23 \%$ (emarketer.com, 2015). Internet menjadi aset dalam berbisnis yang menciptakan keunggulan bersaing setiap pelaku bisnis tersebut. Singapore Post (2014) mendata pengguna Facebook, Twitter, Instagram, dan media sosial yang lain sekitar 89 juta jiwa. Besarnya antusias masyarakat tersebut berpeluang besar dalam membantu bisnis online baik melalui penayangan iklan, status, foto, testimonial pelanggan karena tidak adanya tatap muka langsung dengan konsumen.

Testimonial dapat berupa writing, liking, sharing, recomending, commenting, dan tweeting dan dapat berujung pada pembelian produk. Berdasarkan survey yang dilakukan Kemenkominfo, 90\% konsumenlebihterpengaruh dengan testimoni yang dilakukan oleh orangorang yang sudah dikenal. Konsumen lebih memilih menceritakan pengalamannya melalui media sosial dibandingkan secara langsung (Dichter, 1966; Ryan \& Deci, 2000). Selain itu, melalui media sosial konsumen mendapatkan informasi terkini mengenai produk yang diinginkan seperti merek produk terfavorit, tren model, harga, dan stok yang tersedia (Lin, Lu, \& Wu, 2012 dalam Wolny,J \& Mueller, 2013). Dari beberapa penelitian tersebut dapat disimpulkan bahwa semakin banyak testimonial positif atas merek produk maka semakin banyak konsumen yang ingin membeli produk tersebut, begitupula sebaliknya semakin banyak testimonial negatif atas merek produk maka semakin berkurang konsumen yang akan membeli produk tersebut.

Sosial media dapat menjadi strategi pemasaran produk yang dapat menarik konsumen maupun dapat menghilangkan konsumen. Oleh karena itu dapat disimpulkan bahwa E-WOM yang berupa testimonial melalui sosial media sangat berpengaruh saat ini dimana perkembangan teknologi semakin memudahkan seseorang untuk mengakses media sosial dimanapun dan kapanpun. Selain itu motivasi apa yang melatarbelakangi seseorang untuk terlibat dalam E-WOM melalui media sosial.

\section{REVIEW LITERATUR DAN HIPOTESIS}

Teori tindakan beralasan berguna dalam memprediksi niat berperilaku. Menurut Ajzen dan Fishbein (1975), sikap terhadap perilaku didefinisikan sebagai perasaan positif atau negatif individu seseorang untuk melakukan sesuatu. Hal ini ditentukan melalui penilaian keyakinan seseorang mengenai konsekuensi yang timbul dari perilaku dan evaluasi keinginan dari konsekuensi ini. Jika dihubungkan dengan penelitian ini, peran sosial atau getok tular (word of mouth) dari teman pada toko online sangat mempengaruhi sikap dan tindakan (komitmen) seseorang ingin berbelanja pada toko tersebut dan akan diikuti oleh niat pembelian dan tindakan pembelian secara aktual (Jarvenpaa et al., 2000 dalam Lim et al., 2006). Produk high involvement perlu perencanaan yang matang karena memiliki resiko yang tinggi. Produk high involvement biasanya memiliki merek ternama dan populer di mata konsumen.

H1: Semakin tinggi komitmen seseorang pada sebuah produk (brand involvement), semakin tinggi frekuensi dalam komunikasi e-word of mouth

WOM pada dasarnya dipengaruhi oleh tiga sumber, yaitu motivasi, peluang, dan kemampuan (East, Vanhuele, dan Wright, 2008 dalam Wolny \& Mueller, 2013). Ada empat macam motivasi : product involvement, self involvement, other involvement, dan message involvelment (Dichter, 1996 dalam Wolny \& 
Mueller, 2013). Product atau brand involment adalah perasaan positif pada suatu merek dan tidak mudah untuk dirubah (Beatty \& Kahle, 1988 dalam Wolny \& Mueller, 2013). Hur, Ahn, dan Kim (2011) mengidentifikasikan komitmen terhadap merek sangat memotivasi seseorang dalam aktifitas komunitas.

H2: Semakin tinggi ketertarikan seseorang pada sebuah produk (product involvemnt) berpengaruh pada frekuensi melakukan komunikasi $E$-WOM terkait dengan merek produk tersebut

H3: Semakin tinggi motivasi seseorang secara pribadi (self involvement) berpengaruh pada frekuensi melakukan komunikasi E-WOM terkait dengan merek produk tertentu

H4: Semakin tinggi motivasi seseorang pada orang lain (other involvement) berpengaruh pada frekuensi melakukan komunikasi $E$-WOM terkait dengan merek produk tertentu

H5: Semakin tinggi motivasi seseorang pada saran orang lain (advice seeking) berpengaruh pada frekuensi melakukan komunikasi $E-W O M$ terkait dengan merek produk tertentu

H6: Semakin tinggi motivasi seseorang pada kebutuhan interaksi sosial (need social interaction) berpengaruh pada frekuensi melakukan komunikasi $E-W O M$ terkait dengan merek produk tertentu

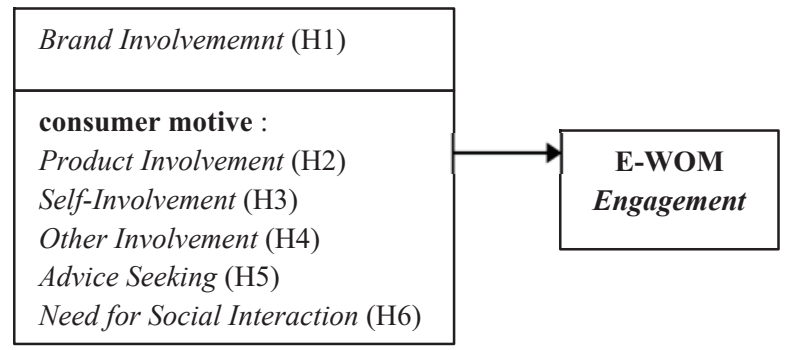

\section{Gambar 1 Kerangka Pemikiran}

\section{METODE PENELITIAN}

Sampel yang digunakan dalam penelitian ini adalah 200 pengguna media sosial yang pernah melakukan testimonial baik writing, liking, sharing, recomending, commenting, dan tweeting atas sebuah produk. Teknik yang digunakan dalam pengumpulan data adalah purposive sampling dengan survei menyebarkan kuisioner kepada responden yang dituju.

Setelah seluruh kuisioner terkumpul, maka dilakukan pengolahan data melalui SPSS dan Regresi Linear Sederhana.

\section{HASIL PENELITIAN DAN PEMBAHASAN}

Dari 250 kuisioner yang disebar, hanya 220 kuisioner yang terkumpul dan 200 kuisioner yang dapat diolah. Dari keseluruhan data dapat digambarkan statistik deskriptif responden sebagai berikut :

Analisis ini memberikan gambaran secara terperinci tentang profil responden mengenai situs online yang serig dikunjungi, jenis kelamin, usia, pendidikan terakhir, pekerjaan, terakhir mengunjungi situs online, testimonial yang dilakukan dan Situs yang paling sering untuk melakukan testimonial. Berdasarkan penyebaran kuesioner yang telah dilakukan, maka peneliti dapat menyajikan tabel tentang identitas responden pada tabel berikut:

Tabel 1

Statistik Responden

\begin{tabular}{|c|c|c|}
\hline Kriteria & Jumlah & Persentase \\
\hline $\begin{array}{l}\text { Situs yang dikunjungi (dalam } \\
6 \text { bulan terakhir) }\end{array}$ & & \\
\hline Facebook & 56 & 28,00 \\
\hline Twitter & 33 & 16,50 \\
\hline Google + & 42 & 21,00 \\
\hline
\end{tabular}




\begin{tabular}{|c|c|c|}
\hline Kriteria & Jumlah & Persentase \\
\hline Instagram & $\underline{69}$ & $\underline{34,50}$ \\
\hline & 200 & 100,00 \\
\hline \multicolumn{3}{|l|}{ Jenis Kelamin } \\
\hline Pria & 117 & 58,50 \\
\hline Wanita & $\underline{83}$ & $\underline{41,50}$ \\
\hline & 200 & 100,00 \\
\hline \multicolumn{3}{|l|}{ Usia } \\
\hline$<16$ tahun & 1 & 0,50 \\
\hline 16-20 tahun & 32 & 16,00 \\
\hline 21-25 tahun & 143 & 71,50 \\
\hline 26-30 tahun & 21 & 10,50 \\
\hline 30-35 tahun & 1 & 0,50 \\
\hline diatas 35 tahun & $\underline{2}$ & $\underline{1,00}$ \\
\hline & 200 & 100,00 \\
\hline \multicolumn{3}{|l|}{ Pendidikan Terakhir } \\
\hline \begin{tabular}{l|l} 
SMP \\
\end{tabular} & 2 & 1,00 \\
\hline SMA & 148 & 74,00 \\
\hline Diploma (D3) & 22 & 11,00 \\
\hline \begin{tabular}{|l|} 
Sarjana (S1) \\
\end{tabular} & 27 & 13,50 \\
\hline Lainnya (D1) & $\underline{1}$ & $\underline{0,50}$ \\
\hline & 200 & 100,00 \\
\hline \multicolumn{3}{|l|}{ Pekerjaan } \\
\hline Pelajar & 2 & 1,00 \\
\hline Profesional & 0 & 0,00 \\
\hline Mahasiswa & 107 & 53,50 \\
\hline Teknisi & 0 & 0,00 \\
\hline Wirausaha & 54 & 27,00 \\
\hline Lainnya & $\underline{37}$ & $\underline{18,50}$ \\
\hline & 200 & 100,00 \\
\hline \multicolumn{3}{|l|}{ Terakhir Mengunjungi } \\
\hline \begin{tabular}{l|l} 
Hari ini \\
\end{tabular} & 162 & 81,00 \\
\hline Kemarin & 28 & 14,00 \\
\hline Seminggu yang lalu & 8 & 4,00 \\
\hline Sebulan yang lalu & 2 & 1,00 \\
\hline Lainnya & $\underline{0}$ & $\underline{0,00}$ \\
\hline & 200 & 100,00 \\
\hline
\end{tabular}

\begin{tabular}{|r|l|c|r|}
\hline \multicolumn{2}{|c|}{ Kriteria } & Jumlah & Persentase \\
\hline \multicolumn{2}{|l|}{ Testimonial yang dilakukan } & \\
\hline & Writing & 18 & 9,00 \\
\hline & Recommending & 1 & 0,50 \\
\hline & Commenting & 27 & 13,50 \\
\hline & Tweet & 24 & 12,00 \\
\hline & Like & 105 & 52,50 \\
\hline & Sharing & $\underline{25}$ & $\underline{12,50}$ \\
\hline & \multicolumn{2}{|c|}{200} & 100,00 \\
\hline Situs yang paling sering untuk melakukan & \\
\multirow{2}{*}{ testimonial } & & \\
\hline & Facebook & 55 & 27,50 \\
\hline & Google+ & 35 & 17,50 \\
\hline & Twitter & 29 & 14,50 \\
\hline & Instagram & $\underline{81}$ & $\underline{40,50}$ \\
\hline & \multicolumn{2}{|l|}{} \\
\hline
\end{tabular}

Sumber : data diolah,, 2017

Berdasarkan tabel 1 diatas dapat disusun penjelasan deskripsi data dari masing-masing statistic responden adalah sebagai berikut:

1. Situs yang dikunjungi (dalam 6 bulan terakhir), responden memberikan jawaban facebook sebesar 28\%, tweeter sebesar $16,5 \%$, google $+21 \%$ dan instagram sebesar $34,5 \%$. Hal ini menunjukkan jejaring social instargam paling banyak dikunjungi oleh responden.

2. Pada jenis kelamin, responden laki-laki sebesar 58,5\% dan wanita sebesar 41,5\%. Angka ini berarti responden laki-laki lebih banyak berpartisipasi dalam memberikan jawaban pada penelitian ini

3. Usia menunjukkan bahwa responden yang berumur $<16$ tahun sebesar 0,5\%, 16-20 tahun sebesar $16 \%$. Usia 21-25 tahun sebesar $71,5 \%, 26-30$ tahun sebesar $105 \%$ dan usia 30-35 tahun sebesar 0.5\%. kemudian pada umur $>35$ tahun sebesar $1 \%$. Hal ini 
menunjukkan bahwa responden usia 21-25 tahuan merupakan responden paling banyak berpartisipasi dibandingkan usia responden lainnya.

4. Pada kategori pendidikan, responden menunjukkan bahwa pendidikan tingkat SMP sebesar 1\%, SMA sebesar 74\%, D3 sebesar $11 \%$, S1 sebesar $13,5 \%$ dan pendidikan lainya (D1) sebesar 0,5\%. Hal ini berarti bahwa responden dengan tingkat pendidikan terakhir SMA memiliki partisipasi terbanyak dibanding responden lainnya

5. Kategori pekerjaan, menunjukkan bahwa pekerjaan pelajar sebesar $1 \%$, professional $0 \%$, mahasiswa $53,5 \%$, teknisi $0 \%$, wirausaha $27 \%$ dan lainnya sebesar 18,5\%. Angka persentase ini menunjukkan bahwa responden dengan pekerjaan sebagai mahasiswa paling banyak dan dominan dalam berpartisipasi dalam mengisi jawab kuesioner pada penelitian ini

6. Waktu terakhir mengunjungi dari semua responden sejumlah 151 responden menunjukkan bahwa terakhir mengunjungi pada hari ini sebesar $81 \%$, kemarin $14 \%$, seminggu yang lalu 4\%, sebulan yang lalu sebesar $1 \%$ dan lainnya $0 \%$. Hal ini berarti bahwa responden rata-rata terakhir mengunjungi pada hari ini.

7. Testimonial yang dilakukan dari jawaban responden pada kategori writing sebesar 9\%, recommending sebesar $0,5 \%$, commenting sebesar 13,5\%, tweeting 12\%, like sebesar $52,5 \%$ dan sharing sebesar 12,5\%. Hal ini berarti bahwa responden sebagian besar melakukan like dalam melakukan testimonial.

8. Situs yang paling sering untuk melakukan testimonial adalah pada facebook sebesar $27,5 \%$, google+ sebesar17,5\%, twitter sebesar $14,5 \%$ dan instagram sebesar $40,5 \%$. Persentase ini menunjukkan bahwa responden sebagian besar melakukan testimonial pada media social instagram.

Selanjutnya data hasil pernyataan 200 responden diolah menggunakan SPSS dan Regresi Linear Sederhana dengan hasil sebagai berikut :

\section{Tabel 2}

\section{Model Summary}

\begin{tabular}{|l|c|r|r|r|}
\hline Model & R & R Square & \multicolumn{1}{c|}{$\begin{array}{c}\text { Adjusted R } \\
\text { Square }\end{array}$} & \multicolumn{2}{|c|}{$\begin{array}{c}\text { Std. Error of the } \\
\text { Estimate }\end{array}$} \\
\hline 1 & $.486^{\mathrm{a}}$ & .236 & .204 & .40944 \\
\hline
\end{tabular}

a. Predictors: (Constant), advice_seeking, Self_ involment, brand_involvement, Need_social, Product involment, other_involment

Dari tabel 2 dapat dilihat bahwa nilai $\mathrm{R}$ sebesar 0,486 artinya bahwa variabel brand involvement, product involvement, self involvement, other involvement, advice seeking, dan need social interaction berpengaruh pada komunikasi E-WOM sebesar 48,6\%. Dengan meilhat standard eror estimate sebesar 0,409 berarti bahwa tingkat keakuratan model ini akurat sebesar 99,591\%.

Tabel 3

ANOVA $^{\mathrm{b}}$

\begin{tabular}{|c|c|c|c|c|c|}
\hline Model & Sum of Squares & $\mathrm{df}$ & Mean Square & $\mathrm{F}$ & Sig. \\
\hline \begin{tabular}{ll|}
1 & Regression \\
\end{tabular} & 7.452 & 6 & 1.242 & 7.409 & $.000^{\mathrm{a}}$ \\
\hline Residual & 24.140 & 144 & .168 & & \\
\hline Total & 31.592 & 150 & & & \\
\hline
\end{tabular}

Dengan melihat nilai signifikansi sebesar 0,00 artinya bahwa secara bersama-sama variabel brand involvement, product involvement, self involvement, other involvement, advice seeking, dan need social interaction berpengaruh pada komunikasi $E-W O M$. 


\section{Tabel 4}

\section{Coefficients $^{\mathrm{a}}$}

\begin{tabular}{|c|c|c|c|c|c|c|}
\hline \multicolumn{2}{|c|}{ Model } & \multicolumn{2}{|c|}{$\begin{array}{c}\text { Unstandardized } \\
\text { Coefficients }\end{array}$} & \multirow{2}{*}{\begin{tabular}{l|} 
Standardized \\
Coefficients \\
\end{tabular}} & \multirow[b]{2}{*}{$\mathrm{t}$} & \multirow[b]{2}{*}{ Sig. } \\
\hline \multicolumn{2}{|r|}{$\mathrm{B}$} & Error & Beta & & & \\
\hline \multirow[t]{7}{*}{1} & (Constant) & 1.447 & .403 & & 3.592 & .000 \\
\hline & brand involvement & .177 & .082 & .175 & 2.159 & .033 \\
\hline & Product involment & .211 & .096 & .212 & 2.196 & .030 \\
\hline & Self involment & .212 & .060 & 312 & 3.524 & .001 \\
\hline & other involment & .135 & .100 & .135 & 1.347 & .180 \\
\hline & Need social & -.422 & .154 & -.272 & -2.733 & .007 \\
\hline & advice seeking & .159 & .062 & .203 & 2.587 & .011 \\
\hline
\end{tabular}

a. Dependent Variable: e_worm

b. T tabel $(1,69)$

Dengan melihat nilai signifikansi sebesar $0,033(<0,005)$ dan nilai t-hitung sebesar 2,159 pada Tabel 4, maka dapat dikatakan bahwa seseorang yang memiliki kesukaan dan kecintaan kepada merek tertentu akan menjadi loyal pada merek tersebut. Dengan loyalitas yang dimilikinya, maka secara tidak sadar akan menjadi marketer dari merek tersebut. Secara positif, orang tersebut akan memberikan informasi yang baik dan positif kepada orang lain terkait dengan pengalamannya menggunakan merek tersebut. Informasi yang diberikan tidak hanya berupa rekomendasi atau kometar tetapi dapat juga share kesukaan (liking). Secara teori snowballing semakin banyak informasi pengalaman yang positif akan terus menyebar semakin besar kepada semua orang. Hal tersebut mendukung hipotesis 1 yang mengatakan bahwa semakin tinggi komitmen seseorang pada sebuah produk (brand involvement), semakin tinggi frekuensi dalam komunikasi $e$-word of mouth.

Selain faktor merek, motif dari konsumen juga dapat mempengaruhi seseorang untuk terlibat dalam komunikasi E-WOM. Seseorang yang tertarik dengan sebuah produk, sebelum melakukan pembelian pasti akan mencari segala informasi terkait dengan produk yang ia inginkan dan termotivasi untuk mendapatkan segala informasi tersebut. Pencarian informasi tersebut dilakukan dengan sharing, bertanya, maupun rekomendasi dari orang lain. Semakin ingin menggali informasi yang lebih, maka semakin orang tersebut meminta saran dan pendapat orang lain melalui media sosial. Sehingga semakin tinggi ketertarikan seseorang pada sebuah produk (product involvemnt), semakin tinggi motivasi seseorang secara pribadi (self involvement), dan semakin tinggi motivasi seseorang untuk mendapatkan saran dari orang lain, maka akan semakin tinggi frekuensi melakukan komunikasi E-WOM. Jika dilihat dari nilai signifikansi sebesar $0,030(<0,005)$ dan t-hitung sebesar 2,196 untuk product involvement, nilai signifikansi sebesar $0,01(<0,005)$ dan t-hitung sebesar 3,524 untuk self involvement, dan nilai signifikansi sebesar $0,01(<0,005)$ dan t-hitung sebesar 2,587 untuk advice seeking maka hipotesis 2, 3, dan 5 terdukung.

Hipotesis 4 mengatakan bahwa semakin tinggi motivasi seseorang pada orang lain (other involvement) berpengaruh pada frekuensi melakukan komunikasi E-WOM terkait dengan merek produk tertentu. Jika dilihat dari nilai signifikansi sebesar $0,180(>0,005)$ dan nilai t-hitung sebesar 1,347, maka hipotesis tersebut tidak terdukung. Semakin berkembangnya jaman dan teknologi, semakin tinggi sifat independen dan individualistik seseorang. Apapun yang dilakukan atas dasar kesadaran dan motivasi diri sendiri, bukan atas dasar orang lain. Komunikasi pada media sosial dilakukan atas kebutuhan, keinginan, dan kesadaran dari diri sendiri bukan karena orang lain.

Jika informasi mengenai produk yang diinginkan sudah didapat dari orang lain baik keluarga maupun teman secara langsung, biasanya akan mengurangi aktifitas pencarian informasi melalui media sosial. Atau sebaliknya jika, dari orang terdekat kurang mendapatkan informasi yang mencukupi, pasti akan meningkatkan frekuensi pencarian informasi terkait produk melalui media sosial. Hasil penelitian ini 
menyatakan nilai signifikansi sebesar 0,07 (> $0,05)$ dan nilai t-hitung sebesar $-2,733$, sehingga tidak sejalan dengan hipotesis 6 .

\section{KESIMPULAN DAN SARAN}

Keterlibatan merek dan motif konsumen yang mempengaruhi komunikasi E-WOM melalui sosial media mendapati bahwa tidak semua motif konsumen tersebut mempengaruhi seseorang untuk melakukan komunikasi E-WOM. Ada 2 hipotesis yang tidak terdukung dalam penelitian ini. Penelitian ini menemukan bahwa semakin tinggi seseorang sudah berinteraksi dengan orang lain, maka akan semakin rendah orang tersebut dalam melakukan komunikasi E-WOM melalui sosial media. Begitu juga terkait motivasi yang muncul karena orang lain tidak akan berpengaruh pada komunikasi yang dilakukan melalui sosial media.

Jika mengacu pada hasil penelitian ini, dengan melihat nilai $\mathrm{R}$ pada Tabel 3, masih ada $51,4 \%$ faktor lain yang mempengaruhi komunikasi E-WOM. Bagi penelitian selanjutnya dapat menggali dan menemukan lebih banyak lagi motif yang mempengaruhi seseorang dalam melakukan komunikasi E-WOM melalui sosial media.

\section{DAFTAR PUSTAKA}

Abedniya,A \& Mahmouei, S.S. 2010. The impact of social networking websites to facilitate the effectiveness of viral marketing. International Journal of Advanced Computer Science and Applications, 1(6), 139-146

Ajzen, I \& Fishbein, M. 1980. Understanding attitude and predicting social behavior. Engelwood Cliffs, NL : Prentice-Hall
Alexa. 2016. "Situs Media Sosial Terpopuler di Indonesia". Diakses pada 22 Mei 2016. http://www.alexa.com

Badan Pusat Statistik. 2016. "Pertumbuhan Ekonomi Indonesia". Diakses pada 19 Mei 2016. http://www. bps.go.id/brs file/pdb 19mei16.pdf

Bampo,M.,Ewing,M.T., Mather,D,R., Stewart,D., \& Wallace,M. 2008. The iffect of the social structure of digital networks on viral marketing performance. Information Systems Research, 19 (3), 273-290. doi: 10.1287/isre.1070.1052

Baron, R, \& Kenny, D,.1986. The ModeratorMediator Variable Distinction in Social Psychological Research: Conceptual, Strategic, and Statistical Considerations. Journal of Personality and Social Psychology, vol. 51, no. 6

Beatty, S. E., \& Kahle, L. R. (1988). Alternative hierarchies of the a ttitude-behavior relationship: The impact of brand commitment and habit. Journal of the Academy of Marketing Science, 16, 1-10. doi: 10.1177/009207038801600202

Berger, Jonah. 2014. Word of mouth and interpersonal communication: A review and directions for future research. Journal of Consumer PsychologyVol. 24 no. 4 p. 586-607

Budiman,Arif.,Heang Chhor, RohitRaz dan, and Ajay Sohoni. 2012. The new Indonesian consumer. Mckinsey Quarterly. December.

Bughin, J, Doogan,J , and Vetvik O. 2010. “A new way to measure word-of-mouth marketing."Mckinsey Quarterly no. 2 : $113-116$ 
Cooper, D.R. and P.S.Schindler. 2011. "Business Research Method". 11th edition. Avenue of the Americans, New York: McGrawHill.

Dichter, E. (1966). How word-of-mouth advertising works. Harvard Business Review, 44(6),147-166. doi: 10.1136/ jech.2005.045203

Emarketer. 2015. Diakses pada 15 Desember 2015. http://www.emarketer.com

Engel, James F., Robert J. Kegerreis and Roger D. Blackwell. 1969. Word-of-Mouth Communication by the Innovator. Journal of Marketing, Vol. 33, No. 3 pg. 15-19

Ghozali, I. 2011. "Aplikasi Analisis Multivariate dengan Program IBM SPSS 19". Edisi: 5. Badan Penerbit Universitas Diponegoro, Semarang

Globalwebindex. 2016. Peringkat Negara Pengguna Internet Terbesar di Dunia. Diakses pada 22 Mei 2016. http://www. globalindex.net

Hair, J.F, William C.Black, Barry J.Babin, dan Rolph E. Anderson. 2010. "Multivariate Data Analisis". 7th edition New Jersey : Pearson Education,Inc.

Hennig-Thurau, T., Gwinner, K.P., Walsh, G. and Gremler, D.D. 2004. "Electronic word-of-mouth via consumeropinion platforms: what motivates consumers to articulate themselves on the internet?",Journal of Interactive Marketing, Vol. 18 No. 1, pp. 38-52.

Hennig-Thurau, Thorsten, Edward C. Malthouse, Christian Friege, Sonja Gensler, LaraLobschat, ArvindRangaswamy, Bernd Skiera. 2010. The Impact of New Media on Customer Relationships. Journal of Service Research Vol. 13 pg. 311
Hennig-Thurau, Thorsten, Caroline Wiertz, \&Fabian Feldhaus. 2014. Does Twitter matter? The impact of microblogging word of mouth on consumers' adoption of new movies.Academy of Marketing Science. April 2014

Hur, W. M, Ahn S. H., \& Kim, M. (2011). Building brand loyalty through managing brand community commitment. Management Decisions, 49(7), 1194-1213.

Kamtarin, Milad. 2012. The Effect of Electronic Word of Mouth: Trust and Perceived Value on Behavioral Intention from the Perspective of Consumers, International Journal of Academic Research in Economics and Management Sciences. Vol. 1, No. 4 ISSN: 2226-3624

Keller, E. (2012). The value of close encounters. Quoted in J. Hurwith. Retrieved from http://womma.org/ word/tag/keller-fay/

Keller, E., \& Berry, J. (2006). Word-of-mouth: The real action is offline. Advertising Age, 77,20-28.

Keller, E., \&Libai, B. 2009.“A Holistic Approach to the Measurement of WOM: It's Impact on Consumer's Decisions". Worldwide Multi-Media Measurement, ESOMAR: Stockholm

Kominfo. 2016. "Kemkominfo: Pengguna Internet di Indonesia Capai 82 Juta". Diakses pada 22 Mei 2016 http:// kominfo.go.id/index.php/content/ detail/3980/Kemkominfo $\% 3 \mathrm{~A}+$ Penggu na+Internet+di+Indonesia+Capai $+82+\mathrm{J}$ uta/0/berita satker\#.U 4NXcV t p0

Lim, K.H., Choon Ling Sia., Matthew K. O. Lee and Izak Benbasat . 2006. "Do I Trust 
You Online, and If so, Will I Buy? An Empirical Study of Two Trust-Building Strategies" . Journal of Management Information Systems. Vol. 23, No. 2.

O'Cass, A. (2004). Fashion clothing consumption: Antecedents and consequences of fashion clothing involvement. European Journal of Marketing, 38(7), 869-882. doi: 10.1108/03090560410539294

Ryan, R. M., \& Deci, E. L. (2000). Selfdetermination theory and the facilitation of intrinsic motivation, social development, and well-being. American Psychologist, 55(1), 68-74. doi:10.1037/0003-066X.55.1.68

Schiffman, L., \& Kanuk, L. (2006). Consumer behaviour (9th ed.). Upper Saddle River, NJ: Prentice Hall.

Sotiriadis, Mario D. \& Cina Van Zyl. 2013. Electronic word-of-mouth and online reviews in tourism services: the use of twitter by tourists. Electronic Commerce Research Vol. 13 p.103-124
Strauss, J. \& R. Frost. 2009.E-Marketing. 5th Edition. New Jersey: Pearson Education.

Trusov, M., Bucklin, R. E., \& Pauwels, K. (2009). Effects of word-of-mouth v traditional marketing: Findings from an Internet social networking site. Journal of Marketing, 73(5),90-102. doi: $10.1509 / \mathrm{jmkg} .73 .5 .90$

Weber, L. (2009). Marketing to the social web: How digital customer communities build your business. London: Wiley.

Xiaofen, J., \& Yiling, Z. (2009, May). The impacts of online word-of-mouth on consumer's buying intention on apparel: An empirical study. International Symposium on Web Information Systems and Applications, pp. 24-28, Nanchang, China.

Zaichkowsky, Judith Lynne.1985. Measuring the Involvement Construct. Journal of Consumer Research, Vol. 12, No. 3, pp. 341-352 